\title{
Significance of the Position and High at Solar Chimney Performance on Dense Low-cost House in Warm Humid Climate
}

\author{
Sugini $^{*}$, Etik Mufida $^{2}$ \\ 1,2, Universitas Islam Indonesia, Yogyakarta, Indonesia \\ $\underline{\text { sugini@uii.ac.id }}^{{ }^{*}}$
}

Received: 10 $\quad$ Final version received:12 2019 December 2019

The ultimate goal of this research is to develop a solar chimney cooling model in dense residential for the purpose of energy saving and air pollution reduction as a result of active cooling use. The problem is limited to the significance of position and height affecting the performance of vertical solar chimney (VSC). The method for the research is adopted from simulation based on empirical data of field measurement. The case taken is within the vicinity of Jogoyudan, Yogyakarta Indonesia with warm humid tropical climate. Modelling is done with Pyrosim software. The models tested were 13 models consisting of 1 NSC model, and 12 models with VSC ( 3 variations of VSC height, and 4 variations of VCS position). External data as input is data that represents 3 zones of a house: in the middle, on the edge of the road and on the edge of the river. From the modelling results, it was observed that the behaviour of heat distribution in indoor space was caused by the variation of position and height dimensional variation of VSC stack. Data were analyzed by making comparison and correlation with statistical tool of SPSS. The research conclusions are: (1) The position of VSC is proven to be differentiate significantly on heat behaviour in indoor space; (2) The height of VSC has not been proven to significantly differentiate the behaviour of heat in the indoor space.

Keywords: Passive Cooling; Vertical Solar chimney (VSC); Position and Height of SC; House; Warm Humid Tropical Climate Urban

\section{INTRODUCTION}

\subsection{Energy and Building Operations}

The current issue of energy and sustainable development is something that cannot be ruled out when the increase in energy consumption is still showing alarming acceleration. Meanwhile, energy consumption is not only a benchmark of pressure on energy reserves but also related to the amount of $\mathrm{CO} 2$ emissions released into the air. One factor that determines energy consumption is the operation of buildings. The potential energy saving through the building ranges from $10 \%$ to $40 \%$. Thus, research aimed at energy control in buildings will be highly significant in controlling energy consumption (Hediyanto,2012).

\subsection{Energy, Residential Houses, and Dense Population}

Residential houses are a dominant type of building function, which is also a basic necessity of society. One of the comfort criteria of a residence is related to air comfort, such as temperature, humidity, and air velocity. To be able to conditioned the air in accordance with the standard of comfort, it would be necessary to use air conditioning system (AC). If at first the use of air conditioning is considered a luxury and is only used in homes with upper economic levels, it is no longer the case nowadays. The higher the temperature of the environment and the easier access to technology, the more widespread use of air conditioning in the middle to lower society. Thus, the excessive use of air conditioning in buildings becomes more rampant. This condition especially happens in urban environments and areas densely populated. Hence, research on energy control for residential buildings in a densely populated housing area is considered to be critical and important.

Yogyakarta is one city in Indonesia that plays an important role for this research. The growth of urban intensity fosters density in urban settlements. One of the important downtown buffer areas is the Jogoyudan area. Yogyakarta Indonesia is an area with warm humid climate. 
The humid tropical climate conditions are characterized by high temperatures and humidity that leads to thermal discomfort.

The achievement of thermal comfort in accordance with the concept of sustainable architecture includes basic building design strategy and passive cooling strategy. Basic building design includes the design of sheath, openings, building masses and shadowing devices (E. Mufida, 2014). Mufida also concludes that the basic design of the building has not significantly played a role in the improvement of thermal comfort of space. To achieve thermal comfort, decrease in room temperature still needs to be supported by the movement of air in space with a certain speed. This natural air ventilation strategy is appropriately used if deeper interior temperatures, which occur due to internal heat, gained due to solar radiation, rather than outer space temperatures (E. Mufida, 2013).

\subsection{Thermal Performance in Densely Populated Urban Area}

One variable that determines thermal performance is wind speed. The wind speed required for thermal comfort of residential space is the speed of a micro-wind above the ground. The speed of the micro airflow can be calculated by providing a reduction factor of 0.75 to the macro-wind speed obtained by a strategically placed meteorological station that is then reduced again by roughness factor according to the type of urban area of the site. Based on these calculations, the wind velocity in crowded urban areas is only 0.4 (Kuismanen, 2008).

Research conducted by Wicaksono and Risdiono at Pandansimo Beach Bantul, obtained data of wind speed in the morning until afternoon ranged from $2.7 \mathrm{~m} / \mathrm{s}-17.02 \mathrm{~m} / \mathrm{s}$. Based on the assumption that wind speed is almost the same as sea speed or macro-wind speed in Yogyakarta and in reference to Roughness factor table of urban area, it is then calculated that the speed of micro-wind in dense settlement is between 0,81 $\mathrm{m} / \mathrm{s}-5,1 \mathrm{~m} / \mathrm{s}$. The reading for the wind speed of the environment is small, leading to the problem of thermal performance in dense urban areas becoming exceedingly critical ( $\mathrm{H}$. Wicaksono et al., 2016).

Urban residential areas as an element of support of the city's economy are generally inhabited by the middle to lower class economic community.
Houses grown in this environment are organically close together, to forming a dense environment. This research is intended for the setting of densely organic low-cost housing.

\subsection{Solar Chimney Ventilation and Warm Humid Tropical Climate}

Airflow as a potential passive cooling strategy for humid tropical climates can be generated by wind-driven ventilation or buoyancy attributable to variations in air pressure due to buoyancydriven stack ventilation. However, the conventional buoyancy ventilation method has not been able to create sufficient airflow velocity for room ventilation. Non-conventional floating ventilation strategy is expected to cover the shortfall. One building commonly used for this floating ventilation is solar chimney.

Research in non-tropical climate areas was carried out by Gontikaki et al. This research studied the application of solar chimneys for natural ventilation and natural heating through a solar chimney prototype for multi-story office buildings in the Netherlands. The results obtained from Gontikaki research shows that the length of the chimney is the decisive parameter in the heat release, (Gontikaki,2010). Research in other non-tropical climates is carried out by Ortega. Ortega studied the solar chimney in Norway with high latitude and low solar altitude. Three types of chimney with different air columns, width and glazing construction and solar collector are tested using CFD software model and software. The results concluded that the type 1 chimney effectively produced the highest rate of air flows. With regards to the findings in Norway, this conclusion still needs to be tested for the case of Indonesia where the solar altitude of both countries differ (Ortega,2011). Neves et al developed a solar chimney in a different variation from Ortega et al. Ortega had developed three variants of a solar chimney intended to gain stack height. On the other hand, Neves developed a solar chimney variant to capture high-altitude solar radiation, resulting in a more acceptable height. This research prioritizes the absorption of solar radiation with high altitude through the absorption field with low inclination. However, this results in a decrease of the expected wind speed. Thus, this research is important to be continued by developing a variant of solar chimneys that can absorb maximum solar radiation with high altitude at the same time to increase the rate of wind speed for areas with 
humid warm tropical climate, such as Indonesia.

Based on the results of the previous research, it can be concluded that the solar chimney can be applied in areas with low wind speeds to create sufficient airflow for physiological cooling and air exchange between the inner and outer space. The question of how to create a solar chimney design in an area with low wind speeds and high altitude in humid tropical region like Indonesia still lingers. The design of the solar chimney should be able to create a high temperature difference between the outer and inner spaces, with no interruption of heat conduction between parts of the building, with optimum inlet and outlet altitude differences, resulting in airflow at sufficient speed for physiological cooling of the body and buildings.

\subsection{Research Objective}

This research is part of a research roadmap aimed at developing the best model of solar chimneys to cool the air in densely populated residential accommodations in humid tropical area. This research limits the study purpose on identifying the significance of the presence, height and position on vertical solar chimney performance.

\subsection{Research Questions}

The research questions are: (1) Does the existence of vertical solar chimney make a difference to the indoor thermal performance, (2) Does the VSC height difference make a significant difference in VSC performance, and (3) Does the position difference of vertical solar chimney give differences in VSC performance?

\section{RESEARCH METHODS}

\subsection{Data collecting, modeling and sampling}

The research is done by taking primary data in the field from selected case. This research is located in Jogoyudan, Yogyakarta, Indonesia. The environmental condition in this research is modest housing that grows organically in the middle of the city. Field data is collected within several stages. The first stage is the initial observation to determine the homogeneity of environmental conditions. From preliminary observations, a sample was determined representing different densities and anatomy of environment. The first type is a house flanked in the middle by other houses. The second type is a house that has a road face. The third type is a house by the river. The next step is measuring air temperature, wind and humidity of the inner and outer space in the sample houses. The variations of building models are being processed for model abstraction into building models simulated with Pyrosim software.

\subsection{Modeling and sampling}

Model abstraction is done by taking modes with modifications as necessary. Field data are being entered into the model. The model tested a number of 13 models. Model $1: 100$ can be seen on Figure 1. Model 1 is a model without solar chimney (non sc). Twelve other models are models with vertical solar chimney (vsc) with 4 different positions. Based on the variation of the house in the field, the $3 \times 6$ dimensioned model with roof grill form with a $30^{\circ}$-slope roof is $3 \mathrm{~m}$ high. Position variations are as follows: (1) in the middle of space, (2) $1 \mathrm{~m}$ from center, (3) $2 \mathrm{~m}$ from middle and (4) $2,85 \mathrm{~m}$ from middle or attached to wall). Each position has 3 models: (1) home with $1 \mathrm{~m}$ high solar chimney from the roof; (2) $2 \mathrm{~m}$ from the roof and (3) $3 \mathrm{~m}$ from the roof. Point of measurement performed on each model are 4 points: (1) The height of the person sleeping, $0.4 \mathrm{~m}$; (2) the height of a person sitting, $1 \mathrm{~m}$; (3) height of person standing, $1.6 \mathrm{~m}$ and (4) ceiling height, $3 \mathrm{~m}$. The research variables are air temperature (ta), wind speed (V), sc height, sc position and occupant position / height of measurement. By limiting the 60-second simulation, the amount of data maintained is 22078.

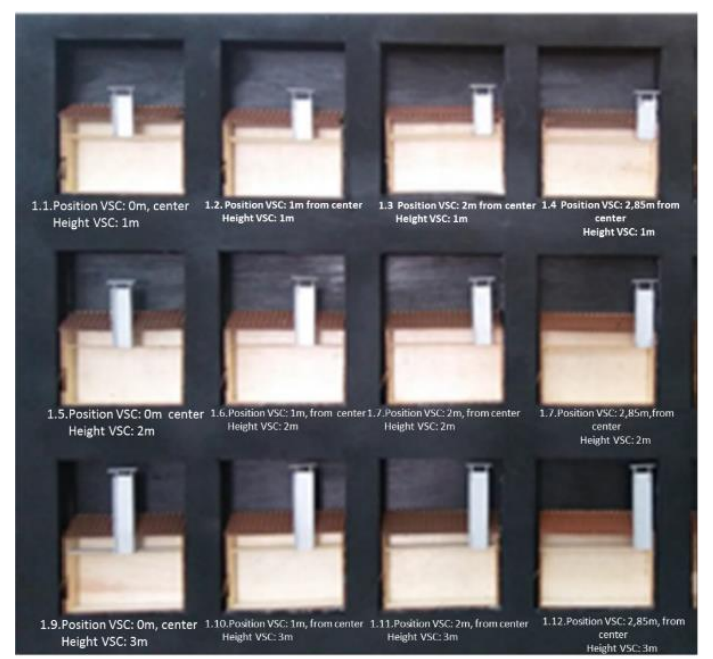

Figure 1: Twelve VSC variations on home models. The house model is based on the simplification of real conditions in the field. 


\section{RESULTS AND DISCUSSIONS}

Based on field empirical data, the room temperature is $31.79^{\circ} \mathrm{C}$. This data is higher than Sugini's research in 2014 (Suguni et. Al, 2014) with Sleman, sub-urban Yogyakarta. The condition indicates that the selection of urban location becomes highly significant on the development of solar chimney. Based on the results of SPSS analysis and empirical data input on sc model without sc, the average thermal performance of air temperature is $31.89^{\circ} \mathrm{C}$. As for the model with sc $32.05^{\circ} \mathrm{C}$, the data distribution can be seen in Fig.2.a and Fig.2.b.

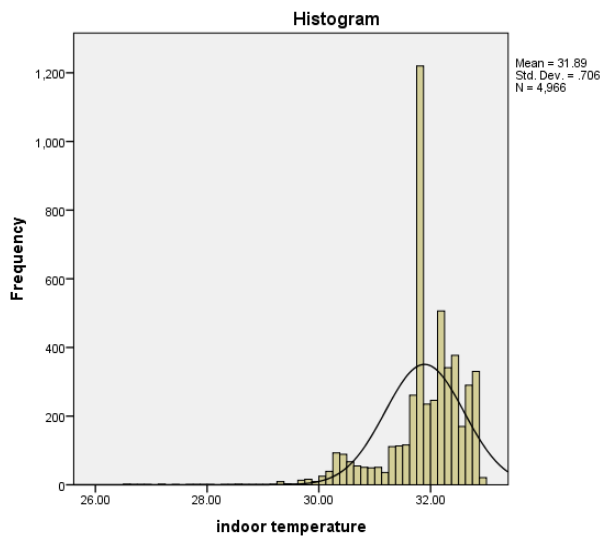

Figure 2.a: Pattern of Indoor Temperature Data Distribution

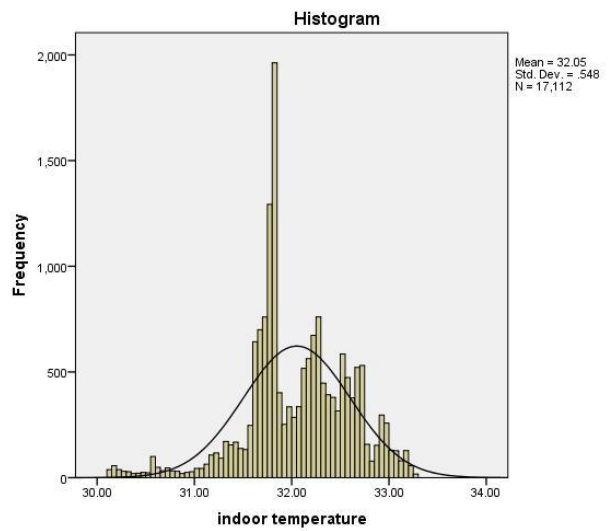

Figure 2.b: Pattern of Indoor Temperature Data Distribution

An overview of data distribution patterns based on differences in measurement points can be seen in Figures 3.1 to 3.6. Figures 3.1 to 3.6 are results examples of the distribution pattern at the measuring point center and $1 \mathrm{~m}$ from the center with different height point of measurement.
Visually the example of the thermal performance pattern of the simulation results can be seen in Fig. 4.1. (a), (b), (c) and Fig. 4.2. (a), (b), (c). Based on comparative test with $95 \%$ confidence level, the result shows that there is a significant difference between thermal performance of air temperature between conditions with solar chimneys and those without solar chimney. This results obtained answer the first question of this research, which is the existence of solar chimney gives a significant difference in the thermal performance of space. Further comparison tests were performed on the model group with solar chimneys. In the comparison test of thermal performance at different altitudes, insignificant results were being observed. Based on analysis, it can be seen that changing the altitude of solar chimney will not produce a difference in air temperature performance.

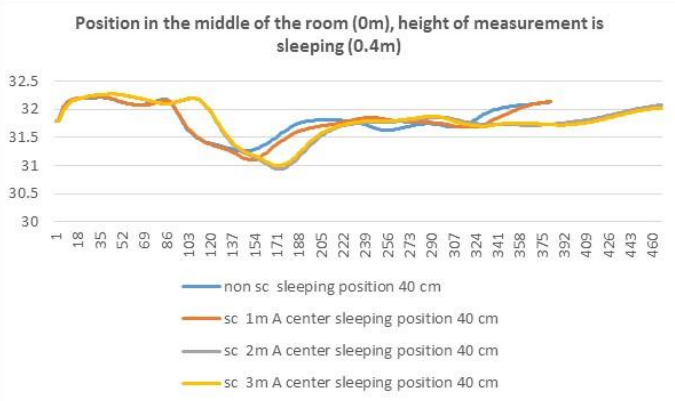

Figure 3.1: The distribution pattern at the measuring point $0,4 \mathrm{~m}$, at the center of the room

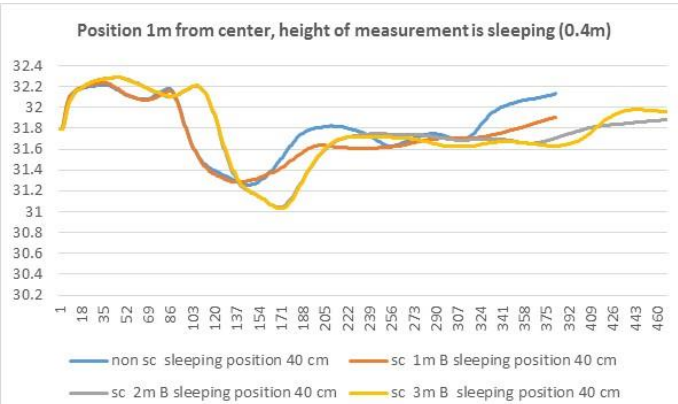

Figure 3.2: The distribution pattern at the measuring point $0.4 \mathrm{~m}$, at the $1 \mathrm{~m}$ from center of the room 


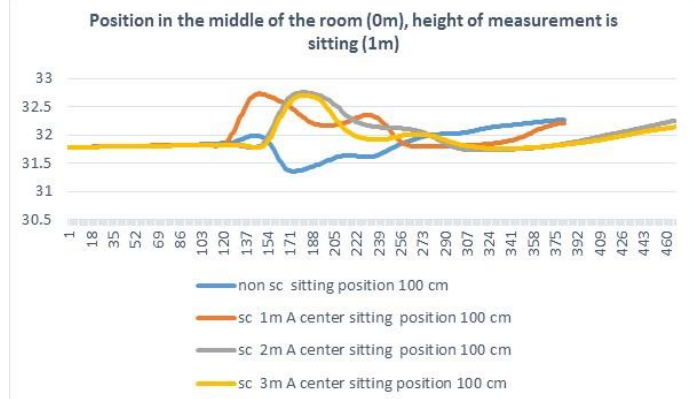

Figure 3.3: The distribution pattern at the measuring point $1 \mathrm{~m}$, at the center of the room

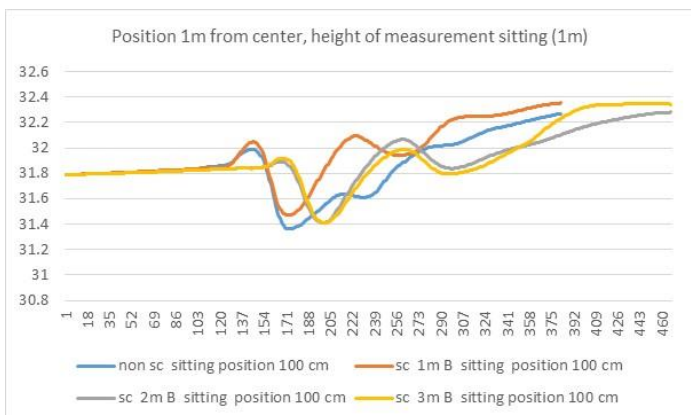

Figure 3.4: The distribution pattern at the measuring point $1 \mathrm{~m}$, at $1 \mathrm{~m}$ from the center of the room

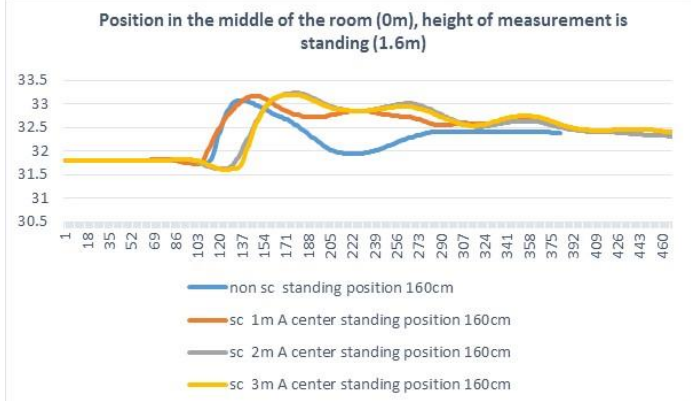

Figure 3.5: The distribution pattern at the measuring point $1.6 \mathrm{~m}$, at the center of the room

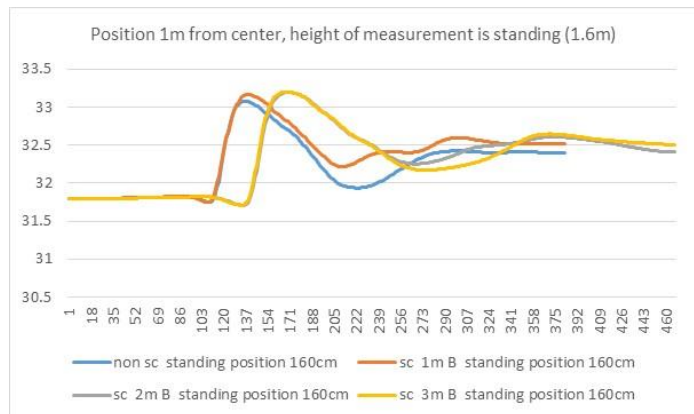

Figure 3.6: The distribution pattern at the measuring point $1.6 \mathrm{~m}$ at the $1 \mathrm{~m}$ from center of the room
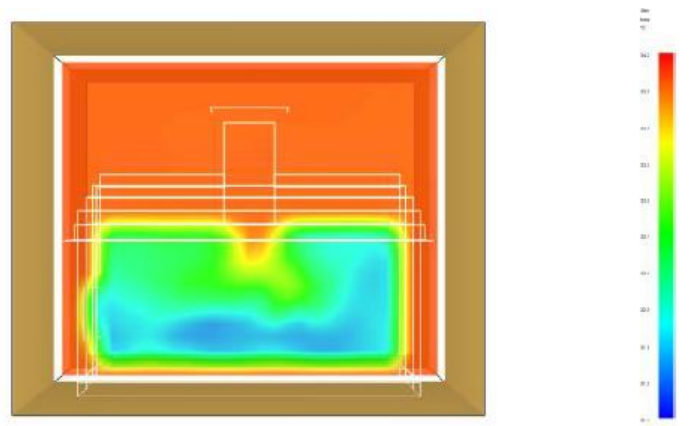

a. Height 1m, position center

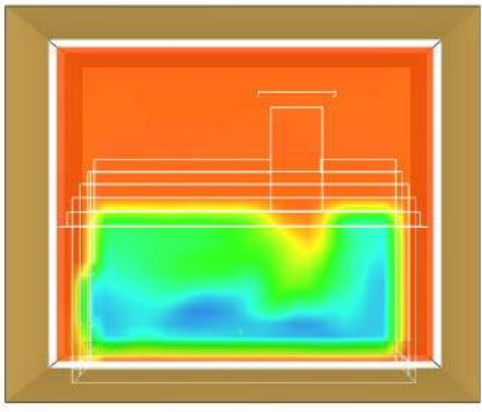

b. Height $1 \mathrm{~m}$, position $1 \mathrm{~m}$ from center

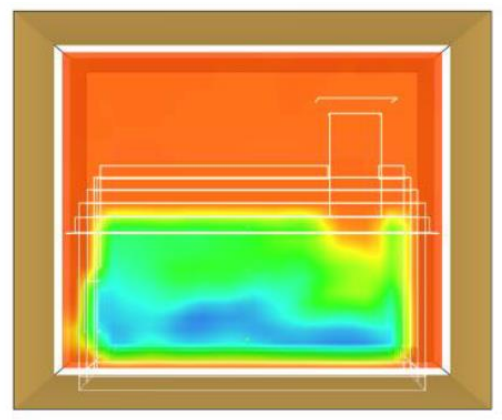

c. Height $1 \mathrm{~m}$, position: $2 \mathrm{~m}$ from the center Fig. 4.1.: Example of Thermal Performance Pattern on Sample Model Test Results of $1 \mathrm{~m}$ height VSC with different position : a. center, $b$. $1 \mathrm{~m}$, c. $2 \mathrm{~m}$ from center
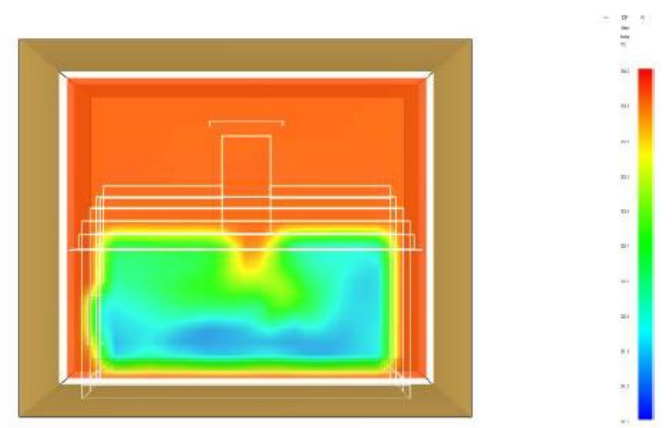

a. Position center: Height: $1 \mathrm{~m}$ 


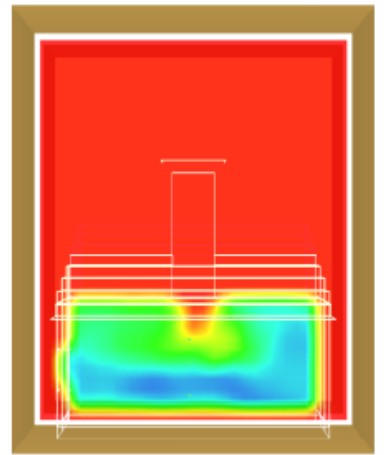

b. Position center, Height: $2 \mathrm{~m}$

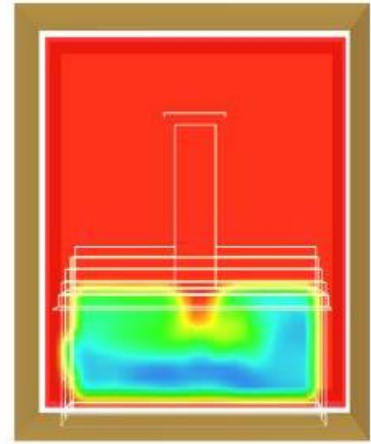

c. Position center, Height:3m

Fig. 4.2.: Example of Thermal Performance Pattern on Sample Model Test Results of center position VSC with different height: $a .1 \mathrm{~m}, \mathrm{~b}$. $2 \mathrm{~m}$, c. $3 \mathrm{~m}$

The thermal performance comparative test based on the difference in the position of solar chimney shows different results with height difference. If the height difference does not make a significant difference, then the difference in position actually gives a significant difference in thermal performance of air temperature.

This study shows that the presence of solar chimney significantly distinguish the performance of VSC base on room air temperature. These results reinforce the notion of passive solar chimney cooling is potential to be developed and to be part of a thermal comfort achievement strategy in a dense urban housing environment. This is in line with the opinion of X.Q. Zhai *, Z.P. Song, R.Z. Wang, (2011) and L. Shi and G. Zhang, (2016) that solar chimneys have the potential to solve ventilation problems, potentially reducing energy demand for ventilation that also reduces $\mathrm{CO} 2$ waste potential, which also corresponds to Long Shia et. $\mathrm{Al}, 2018)$. The next question to be answered is how should the development of solar chimney be done. What variable is more important in determining the performance of solar chimney?
What is the variable height or position of solar chimney? The second question of this research is about the significance of solar chimney's position on the missile's thermal performance. The position of solar chimney significantly raises the thermal performance difference of indoor space air temperature. These results indicate alignment with research from Somaye Asadia, Maryam Fakharib, Rima Fayazb, Akram Mahdaviparsac (2016) .Somaye et al developed 7 models of solar chimneys to be tested. Three models showed different position configurations. Their conclusion stated that compared to the model with small position difference shows similarity, the model with position far from the center of space shows the best performance.

The second question of this study on the significance of solar chimney heights to the thermal performance of space has also been answered. This study found that the height difference did not make a significant difference. If the research is consistent, the development of solar chimney model should proceed more on other parameters. (Hussain H.et.al, 2018) conducted a solar chimney test with 4 different inlet variations. Although the model is not exactly the same, this research found a significant outlet position that improves the performance of solar chimneys. (Xu Jianliuet.al,, 2013) found that variations in the slope of solar chimney play a significant role in performance. In this research, observations were made on the materials. (Shuangping et.al, 2015) conducted research by combining solar glass chimney material as a recipient of sunlight and heat distortion material on the opposite side so that the heat in the vertical space of the solar chimney can be maintained. This condition will cause buoyancy effect that can be maintained. Similarly, (Esmail M.A. et.al, 2017) combined various materials on the collared chimney tube attached to the wall. Although the model is not exactly the same, it can be concluded that there is a suspicion that the right material combination will be more significant than the height of the solar chimney tube

\section{CONCLUSION}

Based on the results of discussion and elaboration with other researches, the conclusion of this research is as follow:

Three research questions have been answered. First, the presence of solar chimney gives a significant difference. Second, the position of the 
solar chimney is significant in determining the VSC performance, while, three, the height of solar chimney has not been proved to significantly cause differences in VSC performance in this study.

\section{ACKNOWLEDGEMENTS}

This article is part of a research funded from a research grant from Indonesia's Ministry of Research and Technology (RISTEK DIKTI) in 2018. Regarding this matter, the author expressed gratitude to RISTEKDIKTI. In addition, the authors also would like to thank the Islamic University of Indonesia, as an affiliate of the author.

\section{REFERENCES}

E. Mufida, "Comparative Study of Thermal Performance on Various Buildings of Building Wall Materials in Tropical Climate Damp by Using DEROB-LTH Software (Studi Komparasi Unjuk Kerja Termal pada Berbagai Susunan Material Dinding Bangunan pada Iklim Tropis Lembab Deng," Yogyakarta, 2013.

E. Mufida, "The Influence of Various Buildings of Building Roof on the Comfort of Building Space in Warm Humid Tropical Climate (Pengaruh Berbagai Susunan Material Atap Bangunan pada Kenyamanan Ruang Bangunan di Iklim Tropis Lembab)," Yogyakarta Indonesia, 2014.

E. M. A. Mokheimer, M. Raghib, and J. Alsadah, "A novel design of solar chimney for cooling load reduction and other applications in buildings," Energy Build., vol. 153, pp. 219-230, 2017.

Gontikaki, "Optimization of a solar chimney to enhance natural ventilation and heat harvesting in a multi-storey office building," Technical University of Eindhoven, 2010.

H. H. Al-Kayiem, K. V. Sreejaya, and A. O. Chikere, "Experimental and numerical analysis of the influence of inlet configuration on the performance of a roof top solar chimney," Energy Build., vol. 159, pp. 89-98, 2018.

H. Wicaksono, Risdiyono, "Desain dan Analisis Wind Turbine Purwarupa Tipe Propeller Poros Horizontal Menggunakan AirFoil AH79-100 C Berbahan Dasar KompositWicaksono, Risdiyono, Hilmi, 2016,” Teknoin, 2016.
Hediyanto, "Statistical Analysis of Energy Saving on Building Building with Benchmarking Method (Analisis Statistik terhadap Penghematan Energy pada Bangunan Gedung dengan Metoda Benchmarking)," Universitas Indonesia, 2012.

Kuismanen, "Climate-conscious architecture design and wind testing method for climates in change." Oulu University Press, Oulu Finland, 2008.

L. Shi et al., "Developing an empirical model for roof solar chimney based on experimental data from various test rigs," Build. Environ., vol. 110, pp. 115-128, 2016.

L. Shi, G. Zhang, W. Yang, D. Huang, X. Cheng, and S. Setunge, "Determining the in $\mathrm{fl}$ uencing factors on the performance of solar chimney in buildings," Renew. Sustain. Energy Rev., vol. 88, no. March, pp. 223238, 2018.

Neves, Roriz, and D. Silva, "Modelling a Solar Chimney for Maximum Solar Irradiation and Maximum Air Flow for Low Latitude Locations," in Proceedings of Building Simulation 2011, 2011, pp. 14-16.

Ortega, "Analyzes of Solar Chimney Design." Norwegian University of Science and Technology, 2011.

S. Asadi, M. Fakhari, R. Fayaz, and A. Mahdaviparsa, "The effect of solar chimney layout on ventilation rate in buildings," Energy Build., vol. 123, pp. 71-78, 2016.

S. Duan, C. Jing, and E. Long, "Transient flows in displacement ventilation enhanced by solar chimney and fan," Energy Build., vol. 103, pp. 124-130, 2015.

Sugini and Nugraha, "Energy Consumption And Thermal Comfort Favored By The Occupants In The Air Conditioned House," in International Seminar ICSBE, 2014.

X. Jianliu and L. Weihua, "Study on solar chimney used for room natural ventilation in Nanjing," Energy Build., vol. 66, pp. 467-469, 2013.

X. Q. Zhai, Z. P. Song, and R. Z. Wang, "A review for the applications of solar chimneys in buildings," Renew. Sustain. Energy Rev., vol. 15, no. 8, pp. 3757-3767, 2011. 